ISSN 2080-1653

DOI 10.24917/20801653.324.13

\author{
PAWEE BREZDEŃ \\ University of Wroclaw, Poland
}

\title{
Research Topics and Changes in the Spatial Structure of Innovativeness of Polish Industry in 2005-2015
}

\begin{abstract}
The purpose of the paper was to synthetically characterise the changes of spatial differentiation of industry innovation in Poland in 2005-2015 in the context of research problems of innovativeness with the use of the cross product. The availability of data limited the scope of the research. For example, innovative activity was presented through the analysis of the share of innovative units in the total number of industrial enterprises and the size of expenditure on innovative activities incurred by industrial enterprises. The analysis of the share of innovative products in the value of total production and net revenues from sales of innovative products in net revenues from total sales was also made. The analyses mentioned were presented against the research and development situation in Poland as a whole and by voivodeship. Research confirmed that significant spatial diversity distinguishes the spatial structure of innovation in Polish industry by voivodeship. Moreover, it is significant that innovative expenditures show low efficiency.Spatial structure of industry innovativeness in Poland was highly stable in the analysed period. The changes in the spatial structure were insignificant and reached only $4 \%$ in synthetic terms. More substantial transformations of the structure, often of an abrupt character, concerned only the selected features of industry innovativeness.
\end{abstract}

Keywords: change of spatial structure; industry; innovativeness; Polish voivodeships; regional system; spatial differentiation

Received: 30 December 2017

Accepted: 13 August 2018

\section{Suggested citation:}

Brezdeń, P. (2018). Research Topics and Changes in the Spatial Structure of Innovativeness of Polish Industry in 2005-2015. Prace Komisji Geografii Przemysłu Polskiego Towarzystwa Geograficznego [Studies of the Industrial Geography Commission of the Polish Geographical Society], 32(4), 205-226. https://doi. org/10.24917/20801653.324.13

\section{INTRODUCTION}

The article deals with the issue of spatial diversification of the level of industry innovation in Polish voivodeships in 2005-2015 in the context of the study of innovation in regional systems. 
The development of the knowledge-based economy depends on the level of innovation of enterprises introducing new, significantly improved products, advanced technologies and better work organisation systems. High level of innovativeness of industrial entities also has a significant impact on increasing the competitive advantage of the entire economy, allowing it, above all, to use its resources more effectively. From the point of view of the possibility of long-term economic growth, they constitute endogenous sources of development based on the internal human and material capital of a given territorial unit. The increase in innovation, as well as the efficiency of the economy at its various levels, depends on many conditions, including the size and directions of expenditures on research and development, innovative activity in industrial enterprises and the degree of automation of their production processes.

The structural system should be understood as a set of elements ordered according to specific rules of their separation and grouping, and a set of relations existing between these elements. Structural changes bring an increase in labour productivity and have a positive impact on the economic growth of countries and their regions. The contemporary development of the knowledge-based economy makes analysis and assessment of the economy's structures regarding the degree of its modernity and innovation significant.

The study aimed to show selected issues concerning the innovation of Polish industry in 2005-2015, spatial diversification of industrial enterprises by voivodeship and an attempt to synthetically characterise changes in the spatial industry innovation system in Poland over the analysed period through the use of a simple vector calculation. Innovative activities were presented, among others, through analysis of the share of innovative units in the total number of industrial enterprises and the value of expenditure on innovative activities incurred by industrial enterprises per capita. An analysis was also made of the share of sold production of new and significantly improved products in industrial enterprises in the total value of sales and the share of net revenues from the sale of innovative products in total revenues. Complementing the characteristics of industry innovation in individual voivodeships was to determine the level of equipping industrial enterprises in the means of automation of production processes, which made it possible to determine the level of technological advancement of industry in individual voivodeships in the country. The research was, therefore, one-feature and quasi one-feature, i.e. taking into account the synthetic feature - consisting of a more significant number of features, the so-called meta-feature. The meta-feature included the following features: expenditures on R\&D in industrial enterprises in PLN thousands, number of employed in R\&D in industrial enterprises, outlays for innovative activity in industrial enterprises in PLN thousands, the share of innovative products in the value of total production sold, and the number of production lines controlled by a computer. The scope of the issues accepted for the analysis resulted from the availability of data.

The conducted analyses became the basis for determining changes in the spatial structure of industry innovation in Poland in 2005-2015 from a synthetic measure through the use of the vector calculation mentioned. The discussed analyses were presented against the research and development situation in Poland and individual voivodeships. Hence, the study also included spatial analyses concerning, among other things, expenditures on the research and development sphere. The innovative activity also included R\&B activities, which were not directly related to the creation of a specific 
innovation, but created an environment conducive to its creation (Podręcznik Oslo..., 2008: 49). Carried-out analyses concerned innovative enterprises, i.e. those that during the analysed period introduced at least one product or process innovation (new or significantly improved product or a new or significantly improved process).

\section{METHODS AND SOURCES OF DATA}

The applied method of studying structural changes was the type of one-feature research (taking into account one feature) or quasi one-feature (taking into account the synthetic feature - composed of a more significant number of features, the so-called meta-feature). The study used both one-feature and quasi one-feature research.

The meta-feature was expressed in the form of a synthetic measure following the procedure of ordering linear spatial units (Zioło, 1985; Runge, 2006). To determine change in the spatial structure of industry innovation, the vector calculation was applied under the procedure proposed by J. Parysek (1976). "A synthetic measure, and at the same time an image of the spatial structure of industry innovation in particular years, is the column vector $\mathrm{K}_{\mathrm{j}}^{\prime}\left(\mathrm{K}_{1}^{\prime}, \mathrm{K}_{2}^{\prime}, \ldots \mathrm{K}_{\mathrm{n}}^{\prime}\right)$ as a vector carried in m-dimensional Euclidean geometric space. The measure of changes in the spatial structure is the angle between two vectors, for two different time sections carried in the m-dimensional space. For practical reasons, the angles between two vectors are replaced with the cosines of these angles. This function takes values in the range from -1.0 to +1.0 . Thus, the cosine of the angle between two vectors carried in the m-dimensional space is the quotient of the value of these vectors above their scalar product", which is expressed by the formula (Parysek, 1976):

$$
\begin{gathered}
\cos K_{j}^{\prime} K_{k}^{\prime}=\frac{K_{j}^{\prime} K_{k}^{\prime}}{\left|K_{j}^{\prime}\right| \cdot\left|K_{k}^{\prime}\right|} \\
\text { where: } K_{j}^{\prime} K_{k}^{\prime}=\sum_{i=1}^{m} c_{i j}^{\prime} c_{i k}^{\prime} \\
K_{j}^{\prime}=\sqrt{\sum_{i=1}^{m} c_{i j}^{\prime 2}} K_{j}^{\prime}=\sqrt{\sum_{i=1}^{m} c_{i k}^{\prime 2}}
\end{gathered}
$$

The arcsine cosine calculated then allows determining the magnitude of the angle between the vectors, which then allows determining the dimension of the change in the structure under examination. In the interpretation of the applied method, the value of the $\cos$ function $\mathrm{K}_{\mathrm{j}}^{\prime} \mathrm{K}_{\mathrm{k}}^{\prime}=1.0$ means constancy of the structure, $\cos \mathrm{K}_{\mathrm{j}}^{\prime} \mathrm{K}_{\mathrm{k}}^{\prime}=-1.0$ complete inversion of the structure, $\cos \mathrm{K}_{\mathrm{j}}^{\prime} \mathrm{K}_{\mathrm{k}}^{\prime}=0.0$ is the $50 \%$ transformation of the structure, while $\mathrm{K}_{\mathrm{j}}^{\prime} \mathrm{K}_{\mathrm{k}}^{\prime}=0.7071$ is a $25 \%$ change. The features adopted for the analysis for their comparability were normalised using the following formula: 


$$
c_{i j}^{\prime}=\frac{c_{i j}}{\sum_{i=j}^{m} c_{i j}}
$$

where: $c_{i j}^{\prime}$ - means a standardised element of the matrix $P^{\prime}$, i.e. a matrix formed after the transformation of the information matrix of the output data.

The vectors created in this way show the participation of the spatial unit in the studied phenomenon in individual years. The classification of voivodeships in terms of their participation in the national structure of the studied phenomenon was a complementation to the synthetic characterisation of changes in the spatial system of innovativeness of Polish industry using the above-presented vector calculation. As a criterion for the division, participation rates were adopted concerning the average share and standard deviation (Parysek, 1976). The source of data regarding the analysed features was information available in the local data bank.

\section{INNOVATION AS A FACTOR IN THE DEVELOPMENT OF THE ECONOMY}

The issue of innovativeness has significantly gained in importance in recent years, both in scientific discussions and in practice. The popularity of this theme, however, has contributed to the ambiguity of the concepts used and the difficulty in establishing a uniform research methodology. The scope of issues addressed in the framework of innovation research is also extensive. It applies to enterprises, various types of spatial units and numerous aspects of the economy.

In the theory of economics regarding the creation of new scientific achievements, two basic approaches have been formed. The former emphasises the importance of the demand side while the latter - the supply side.

The demand concept is that the primary factor creating innovations are the needs, whose recognition and subsequent transmission of information about their existence from the market to research and scientific institutions causes the process of creating new products, technologies, services, etc. (Schmookler, 1972). In 1912 A.J. Schumpeter created the basis for the supply approach and developed a model of innovative activity, in which the emphasis is placed on the inflow of new ideas from outside science to enterprises whose classic task is to implement innovations. As the industry evolves, Schumpeter has refined his model of stimulating innovation processes. He emphasises the so-called internal science, that is, own research facilities and laboratories of enterprises implementing innovations. External science (research units outside the industry) being an element of the surroundings here, has less influence on the implementation of innovations. Therefore the management processes in the enterprise are the driving force behind the creation of innovations (Schumpeter, 1995; Winiarski, 2002).

A synthetic description of the creation of individual models of the innovation process is presented by D. Marinowa and J. Philimore (2003). In Poland, the innovative environment model is widely understood as complex research, cultural and institutional infrastructure that creates an environment conducive to the emergence and dynamism of innovation (Markowski, 2005). The quality and level of education play an essential role in the creation and implementation of innovative solutions. The above-presented research problems have been undertaken in various studies concerning the role of science in economic development (Kukliński, 1997), in shaping a modern business 
(Carnicky, Krupa, Skotny, 2011), developing creative industries and municipal systems (Stryjakiewicz, Męczyński, 2010; Stryjakiewicz, Stachowiak, 2010). In many studies, attention has also been paid to the importance of innovation in shaping the processes of economic development (Zioło, 2012).

The knowledge-based economy consists of a gradual transition from a material-intensive economy to one that uses the potential of science and information. Intangible assets, especially human capital, knowledge and new technologies gain in importance. Therefore, developmental opportunities are increasingly determined by human intellectual potential and knowledge associated with the latest achievements of modern science. The development of knowledge-based entrepreneurship largely depends on national conditions, favourable public policies and public awareness in this area. The increase in innovation and the introduction of new or significantly improved products or advanced technological processes contribute to the full use of existing resources, as well as increase the efficiency of the economy. Their effect is also the creation of new jobs and an increase in the competitiveness of enterprises and thus the entire regional economy. The high innovativeness of the economy is particularly important in the case of countries transforming their economic structures, to which Poland belongs. It allows for stimulating the process of modernising the economy and reducing the gap in the level of economic development in relation to the technologically advanced countries (Nowak, 2012; Brezdeń, Spallek, 2013; Murzyn, 2013).

The analysis of the structures of the economy or its parts can be considered in various systems. The structural system should be understood as a set of elements ordered according to specific rules of their delimitation and grouping, and a set of relations existing between these elements.

Structural changes bring an increase in labour productivity and have a positive impact on the economic growth of countries and their regions. Structural changes taking place in the objective (generic) system, which characterises the branch structure of the economy, are considered to be particularly important. An important role also lies in the institutional structure, which is of fundamental importance for the shaping of economic relations, as well as for the functioning of the economic system and the appropriate regulatory solutions. The next crucial structural system is the regional (spatial) structure, defining the distribution of elements of the national economy divided into different territorial units. This structure is the subject of research in this study.

The contemporary development of the knowledge-based economy makes analysis and assessment of the economy's structures regarding its degree of modernity significant. The changes taking place in the economy depend on the level of innovativeness of enterprises introducing new, significantly improved products, advanced technologies and better work of organisation systems. The high level of innovativeness of entities also has a significant impact on the growing competitive advantage of regional economies, enabling, above all, more effective use of resources (Zioło, 2010, 2012).

\section{INNOVATION AND CHANGES IN SPATIAL SYSTEMS}

Innovative processes, their effectiveness and proper use, are of great importance for economic development. Especially at the regional level, the importance of proper identification and utilisation of endogenous resources determining internal innovation processes becomes more significant. Their diffusion within the region occurs when 
participants involved in the process of shaping innovations (e.g. enterprises, scientific units, business support institutions, local and national government sectors) establish close relationships leading to the effect of feedback on regional innovation systems.

Innovativeness in the economy can be related to its various aspects, i.e. spatial and subjective. In the spatial aspect, innovation can be applied to the entire economy of the country or its regions. In the case of the subjective aspect, innovativeness focuses on enterprises and individuals (Wach, 2007; Zioło, 2010). The region's innovation should be understood as the ability of the socio-economic and institutional system to create, absorb and diffuse innovations (Olechnicka, Smętowski, 2007).

The level of innovation determines the competitiveness of regional economies, the most significant impact in the case of regions that are sources of knowledge (Golejowska, 2012).

The relations between enterprises, public authorities and scientific resources are presented in the triple helix model (Etzkowitz, Leydesdorff, 2000). In the model, as mentioned above, universities play a crucial role in creating innovative activity, alongside which the sphere of power and economic activity associated with the industry coexist. Numerous authors mention the importance of regional factors shaping the region's innovativeness and enterprises located in it. Some of them indicate that it is not possible to precisely distinguish the regional environment factors, macro-environment factors and factors related to the innovation policy, which can be included both in regional and general factors (Meyer-Krahmer, Gundrum, 1995; Sternberg, Arndt, 2000). Others, however, among the factors conditioning the development of learning organisations, explicitly mention regional factors responsible for the region's innovation. An example of the above view that gives a unique role to regional factors in shaping the innovation of areas is a study by A. Langendijk (2001). The author even calls the regional factors the "regional knowledge laboratory" (Langendijk, 2001). Regional factors play a particular role in creating innovative activities for small- and medium-sized enterprises (Pfirrmann, 1994). The similar significance of regional factors in innovative enterprises' activities and their development is proven by Ch. Oughton, M. Landabaso and K. Morgan (2002). This phenomenon is called the regional innovation paradox. Analysing the conditions of functioning of innovative enterprises in a given region, one should also refer to the territorial concepts of production systems, which - to put it simply - are geographically concentrated industrial zones. The same applies to the innovative milieu model, which in the 1980s was introduced by the French regionalist Ph. Aydalota (1986), and then developed by the GREMI research group (Groupe de Recherche Européen sur les Milieux Innovateurs), among others by the Swiss regionalist D. Maillat (2002). This model tries to incorporate into the framework of the theory various forms of interdependence that arise in a given area, and which, by combining very different elements, affect the development of innovation and the emergence of new technologies. Ensuring the conditions necessary for the existence of an innovative environment at the regional level leads to the creation of innovative enterprises, i.e. the emergence of innovative companies that emanate from the local environment. Therefore, regions referred to as regional production systems or innovative environments are a source of competitive advantage for the entities clustered in them.

In the present informative phase of the economy, the processes of change taking place in it simultaneously influence the functioning and transformation of its entities, cities and various spatial structures (Siłka, 2012; Dzikowski, 2017). In the regions of 
Poland, as well as in other new EU Member States, the global trends of changes related to globalisation are also superimposed by their national conditions. Therefore, these processes create new conditions for the functioning of the essential elements of the economic structure, such as industrial enterprises (Rachwał, 2012). In order to achieve and maintain a competitive advantage on the market, these enterprises have to adapt to new, complex environmental conditions (more in Rachwał, 2008, 2009; Zioło, 2010). In the light of research, enterprises showing favourable conditions for development are those integrating into global industrial networks through investment processes carried out in them by a foreign investor, which translates into more significant opportunities in the field of technical and technological changes and the assortment of products and expanding access to domestic and global markets. An important role is also played by the financial resources of industrial enterprises, depending on the favourable financial and capital condition that determines proper financial liquidity. It allows for the allocation of adequate funds for the modernisation of the machine park and thus obtaining more competitive products concerning quality, function and price (Zioło, 2010). As a consequence, the factors and processes as mentioned earlier influence the development of diversified spatial structures of industry innovation with varying degrees of durability (Brezdeń, 2015).

\section{SELECTED ISSUES OF R\&D AND INNOVATIVE ACTIVITY IN POLAND IN ANALYTICAL TERMS}

The characteristic feature of economic structures is their variability over time. The structural characteristics usually determine the relationship between elements and the whole of the set. In this way, the structure of employment, production, as well as the region treated as an element of a more extensive system (country) or as a whole in itself is described (Klamut, 1996). The broader approach to the structure alongside the quantitative relation also includes quality relations. In this approach, structure research may include its effectiveness.

Structural changes in the economies of developed countries and international economic groups are expressed primarily in the reduction of production and employment in industries with old technology and declining demand for their products, and simultaneous acceleration of the growth rate in industries using modern technologies, for which the demand is growing. This trend is present in all developed industrial countries. However, the pace and scale of change are significantly different in them (Winiarski, 2002).

The main factors of these changes are, among others, development of science and technology. For this reason, a critical system characterising the economy is its structure assessed due to the degree of modernity of manufactured products and technologies used. The increase in innovation and the introduction of new or significantly improved products or advanced technological processes contribute to the full use of the resources possessed, as well as to increasing the efficiency of the economy.

Innovation under the Oslo methodology is the implementation of a new or significantly improved product (goods or service) or process, a new marketing method or a new organisational method in business practice, workplace organisation or relations with the surroundings (Podręcznik Oslo..., 2008: 48). As a rule, product, process, marketing and organisational innovation are distinguished. The study of the innovativeness 
of industrial enterprises at the regional level, due to the availability of statistical data, is only possible about product and process innovation, which is why these categories were accepted for analysis. The set of entities by which the evaluation of the innovativeness of the economy was made are enterprises that introduced at least one product or process innovation (new or significantly improved product or new or significantly improved process) to the market during the period under consideration.

Innovative activity means all scientific, technical, organisational, financial and commercial activities that lead or are intended to lead to the implementation of innovation. Thus, the innovative activity also includes research and development (R\&D) which is not directly related to the creation of a specific innovation, but develops a favourable environment for their creation (Podręcznik Oslo..., 2008: 49). Research and development activity is one of the most critical factors and conditions of innovative activity of enterprises. Its goal is to strive for continuous improvement of its operations, as well as identification of early opportunities and threats for the company.

According to Eurostat data, in 2015 internal expenditure on research and development in Poland accounted for $1.44 \%$ of the expenditure of all 28 European Union member states. Poland ranked 20th among the EU countries regarding the intensity of research and development projects, which was 2.2 times lower for Poland than for the entire EU. The intensity of R\&D works in Poland concerning the EU-28 is lower by 1.03 p.p. In 2015, in Poland (as in Slovakia), the value of the indicator exceeding for the first time $1 \%$ of GDP was recorded. Despite the gradual increase in the value of expenditures on R\&D to GDP from $0.57 \%$ in 2005 to $1.03 \%$ in 2015 , this level is highly unsatisfactory (for more see Gajda, 2015). After converting the value of internal expenditures into R\&D per capita in 2014, with 101.6 Euro Poland took the 23rd place among all EU-28 countries, where the average value of such expenditures was EUR 564.4 (Nauka i technika..., 2016).

The gradual increase in R\&D expenditures in the economy in 2005-2015 was accompanied by a more diversified increase in outlays on innovative activity in industrial enterprises. After a period of their gradual increase in 2005-2008, there was a decline in the value of innovative expenditure by 2013. a significant increase in expenditures took place from 2014, reaching in 2015 over 31 billion PLN. It accounted for more than twice the outlays on innovative activity from 2005 (Fig. 1).

The necessary parameters used in the analysis of the scale of research and development processes in the economy include indicators of internal inputs related to the creation of knowledge. These are Gross Domestic Expenditure on R\&D (GERD), and Business Expenditures on R\&D (BERD). They are related to Gross Domestic Product (GDP) (after Nauka i technika..., 2013). Despite the upward trend in recent years, their level in the entire Polish economy is highly unsatisfactory.

Expenditures on research and development activity show significant spatial differences by voivodeship (Fig. 2).

In 2015, the most significant expenditures on research and development (GERD) activities took place in Mazowieckie Voivodeship with a result of $1.7 \%$. In this voivodeship, there was almost a quarter of all active research entities and $39.2 \%$ of the total number of scientific and R\&D units. High values of the indicator were also characteristic for Małopolskie and Podkarpackie Voivodeships, which achieved the result of $1.38 \%$ of GDP each. The value of the GERD index above 1\% was also recorded in the analysed year in Pomorskie (1.05\%) and Lubelskie (1.03\%) Voivodeships. Much lower values, 
Fig. 1. Expenditure on innovative activity in industrial enterprises in the years 2005-2015

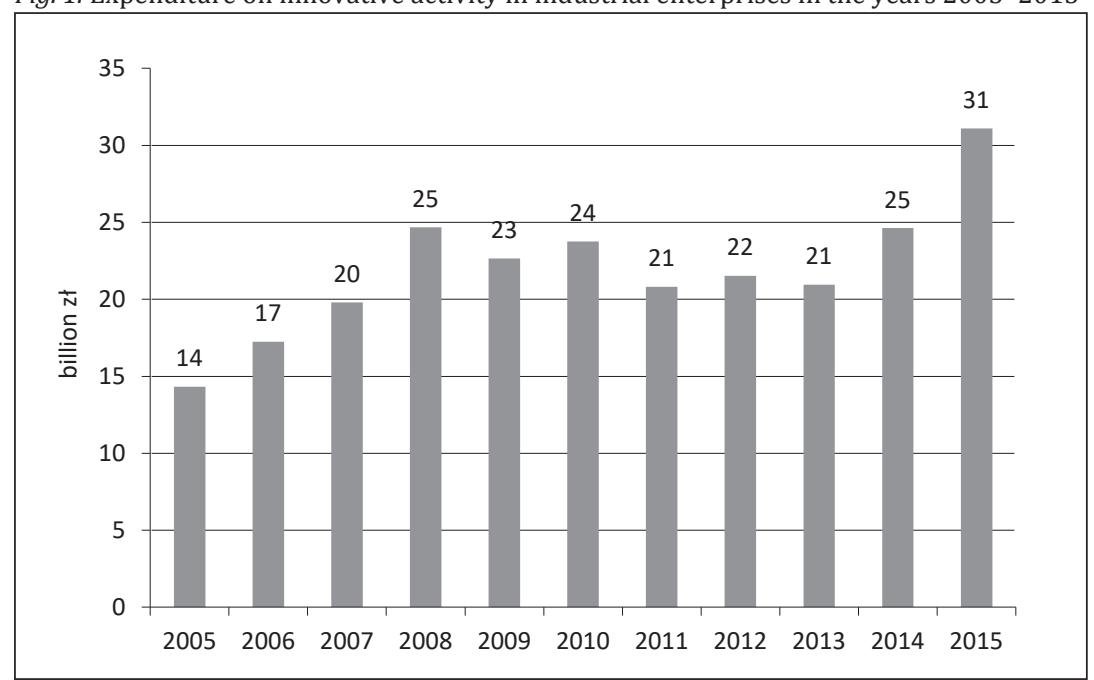

Source: own work based on Bank Danych Lokalnych... (2017)

Fig. 2. Total national expenditures on R\&D (GERD) and expenditure on R\&D in industrial enterprises (BERD) in 2015

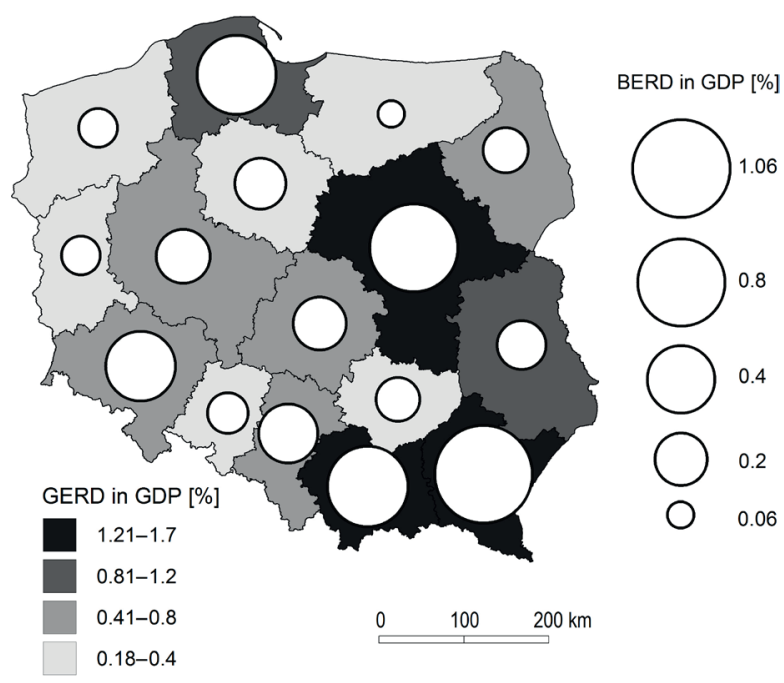

Source: own work based on Bank Danych Lokalnych (2017) and Działalność innowacyjna... (2016)

between $0.41-0.8 \%$, occurred in other, economically well, voivodeships: Dolnośląskie, Wielkopolskie, Śląskie and Łódzkie.

On the other hand, the following voivodeships showed the lowest values: Lubuskie, Warmińsko-Mazurskie, Świętokrzyskie and Opolskie. Spatial distribution of the GERD index did not correspond in all voivodeships with spatial distribution of the BERD indicator. The latter was significantly lower than the GERD index in all Polish voivodeships. 
This relationship is characteristic of less developed countries, in which entrepreneurs find it more advantageous to acquire foreign technology rather than develop their own, which would require the mobilisation of abundant resources. In such economies, research potential is usually sustained by the public sector. Hence the expenditures of enterprises usually constitute a decidedly smaller part of GERD (Diagnoza pogłębiona innowacyjności..., 2012). The highest activity of industrial enterprises concerning expenditure on R\&D was characteristic for Podkarpackie Voivodeship with the result of $1.06 \%$ of GDP. Mazowieckie and Małopolskie Voivodeships obtained the BERD result by half lower than in the case of the GERD index. In Lubelskie Voivodeship the BERD indicator was six times lower than BERD. This more significant gap in the case of the second parameter may indicate that an essential factor strengthening the intensity of $R \& D$ is the presence of public institutions in the region, which incur significant research and development expenditures. Dolnośląskie Voivodeship, concerning total research and development expenditure, was more active in industrial enterprises, which is a very positive phenomenon. It should be remembered that expenditure on research and development accompanies production investments that generate innovative products or technologies with high added value. The few investments of this type in the countries of Central Europe cause that these regions show low productivity, resulting from production with lower added value and low expenditure on R\&D (Rachwał, Wiedermann, Kilar, 2009).

The share of innovative enterprises in industrial enterprises in total in 2015 was close to $14 \%$ in Poland. The most significant percentage of them was recorded in the voivodeships in the south-western part of the country (Śląskie, Opolskie and Dolnośląskie) and in Mazowieckie Voivodship. The lowest, on the other hand, was recorded in Świętokrzyskie, Lubuskie and Kujawsko-Pomorskie Voivodeships (Fig. 3).

A relatively high share was also recorded in the voivodeships of eastern Poland. However, attention is drawn to the considerable decline in the share of innovative industrial enterprises in 2015 as compared to 2005 (Fig. 4).

In a national scale, it amounted to over $60 \%$ in the analysed period. In the regional system, the most substantial change was recorded in the voivodeships of the eastern and northern parts of the country. An unusually large loss of these enterprises (nearly $72 \%$ ) took place in Świętokrzyskie Voivodeship, which at the same time belonged to the regions with the lowest share of innovative enterprises in total. Given the above, the economically weaker voivodeships, in which at the same time the share of these entities was smaller, showed a significant decrease in their share in the period under consideration.

An essential feature in the analysis of industry innovation is the expenditure incurred on this activity in industrial enterprises. Regarding expenditures incurred by these enterprises in PLN per capita, the most favourable situation in 2015 occurred in Mazowieckie, Łódzkie and Dolnośląskie Voivodeships, as well as regions located in the western part of the country (Fig. 5).

The lowest expenditures of less than PLN 400 per capita were found in the voivodeships of eastern and north-eastern Poland. In contrast to the share of innovative industrial enterprises in total enterprises in the case of expenditures incurred on innovative activity in virtually all voivodeships in the country, they increased in the analysed period (Fig. 6). 
Fig. 3. The share of innovative enterprises in industrial enterprises in total in 2015

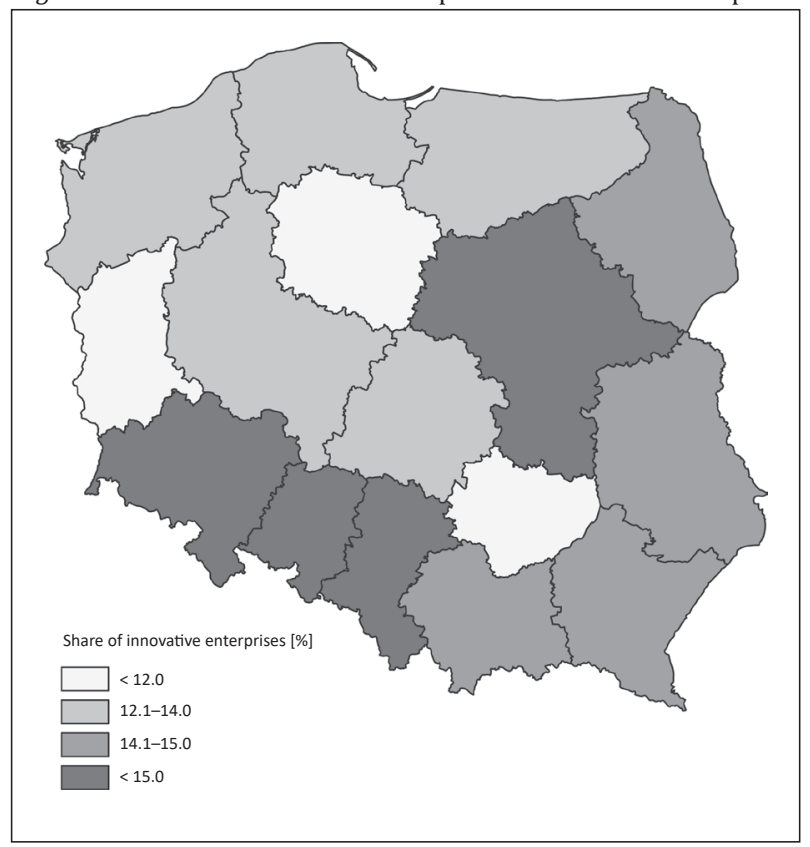

Source: own work based on Bank Danych Lokalnych (2017)

Fig. 4. Change in the share of innovative enterprises in industrial enterprises in total in 2005-2015

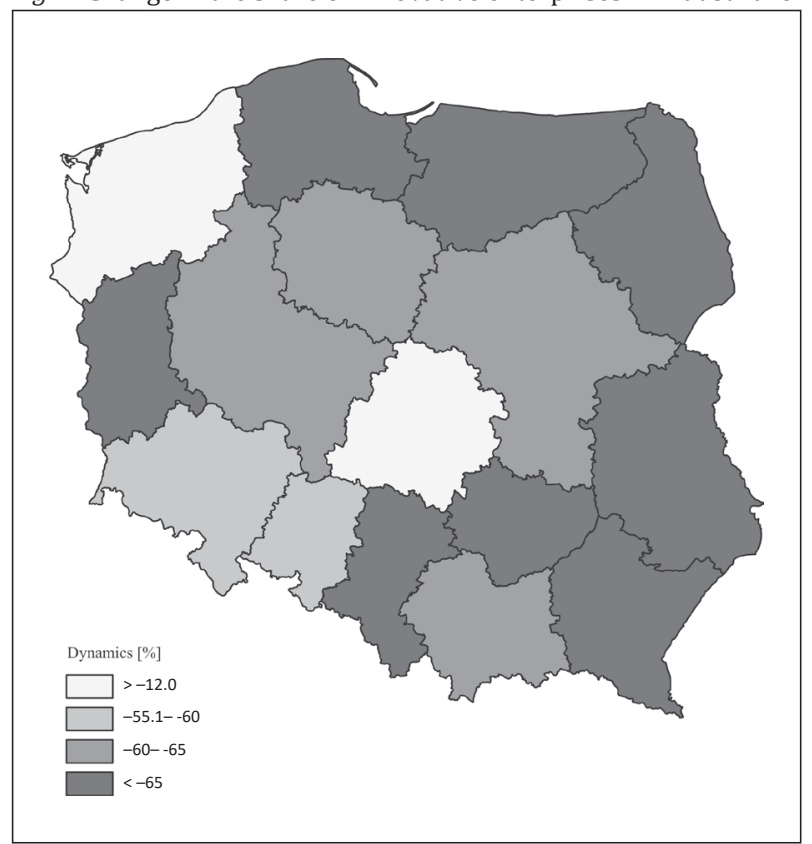

Source: own work based on Bank Danych Lokalnych (2017) and Działalność innowacyjna... $(2013,2016)$ 
Fig. 5. Expenditure on innovative activity in industrial enterprises in 2015

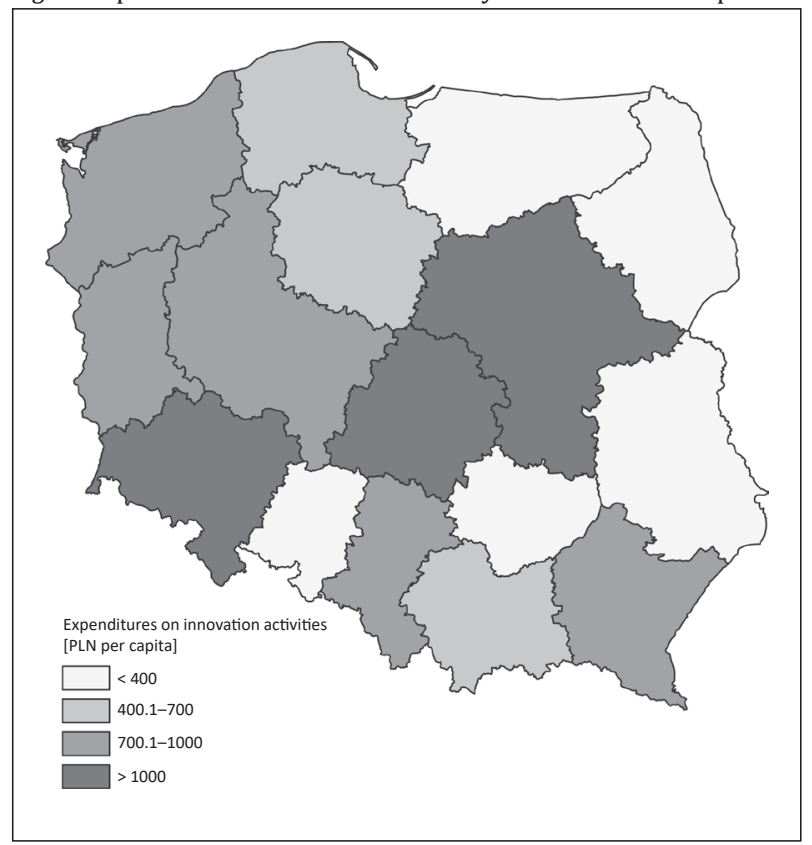

Source: own work based on Bank Danych Lokalnych (2017) and Działalność innowacyjna... (2016)

Fig. 6. Dynamics of innovative expenditure in industrial enterprises in PLN per capita in 2005-2015

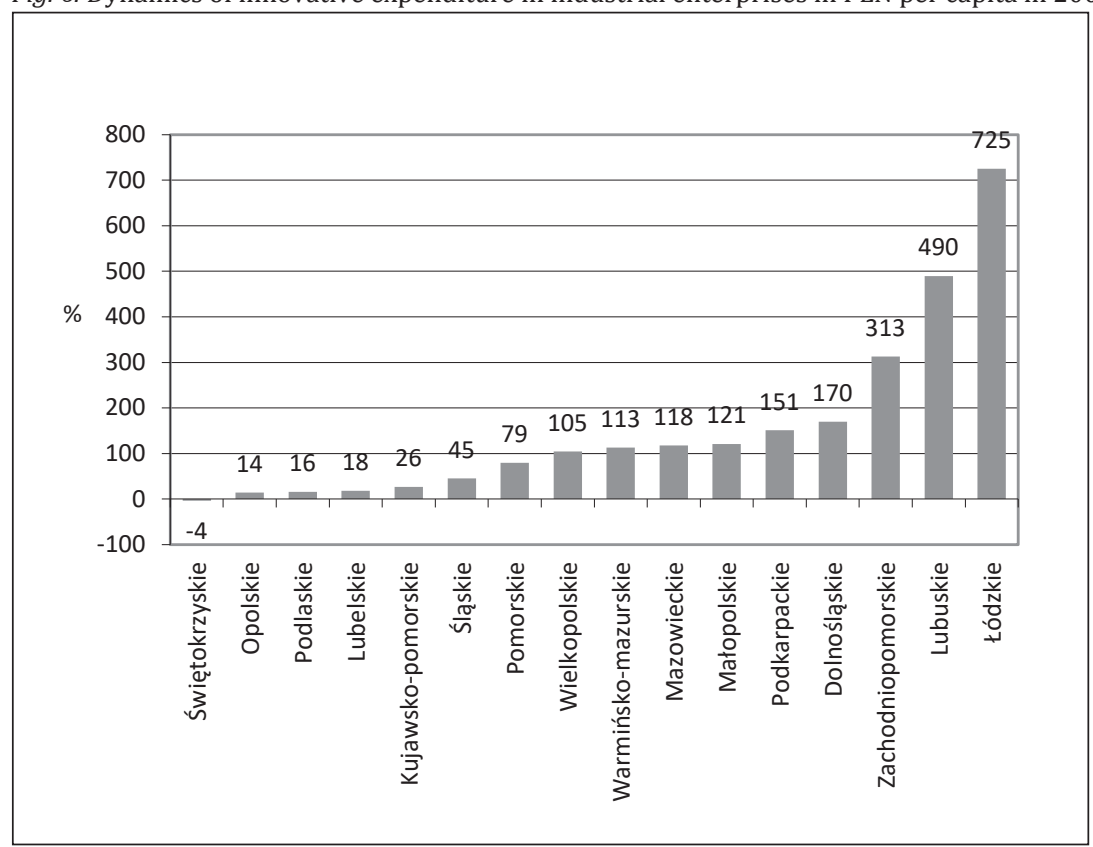

Source: own work based on Bank Danych Lokalnych (2017) and Działalność innowacyjna... $(2013,2016)$ 
The largest was recorded in Łódzkie, Lubuskie and Zachodniopomorskie Voivodeships. However, it should be emphasised that the mentioned administrative units had low values of expenditure on innovative activity in 2005. The only region in which the expenditure on innovative activity dropped was Świętokrzyskie.

An important parameter used in particular for the assessment of the effects of innovative activities of industrial enterprises was the share of sold production of new and significantly improved products in the value of total production sold. The share of the production mentioned above is not high in Poland (more in Nowak, 2012). In 2015, it amounted to $12.5 \%$. The spatial structure of the share of innovative production in the value of total production sold was also significantly diversified by voivodeship (Fig. 7).

The most significant share occurred in Pomorskie, Wielkopolskie and Dolnośląskie Voivodeships where it amounted to over $14 \%$. Relatively high values of this share were also present in the following voivodeships: Śląskie, Małopolskie, Podkarpackie, Łódzkie and Kujawsko-Pomorskie, and were at a level of 10-14\%. The lowest share was recorded in Podlaskie, Warmińsko-Mazurskie, Lubuskie, Opolskie and Świętokrzyskie Voivodeships. In general, it did not exceed the level of $4-5 \%$ of the value of total sales in the mentioned voivodeships. Changes in the share of sold production of new and significantly improved products in the value of total production sold in 2005-2015 were very unfavourable in Poland. The reasons are complicated, starting from the financial crisis that begun in the global economy in 2008. It influenced the investment and export sphere of companies with foreign capital operating in Poland, consolidating the position of the Polish economy as a subcontractor for many companies with German capital, which implement production in Poland that is in the phase of maturity and standardisation of the product lifecycle (more in Brezdeń, 2016). The processes mentioned earlier

Fig. 7. Share of innovative production in industrial enterprises in the total value of sales in 2015

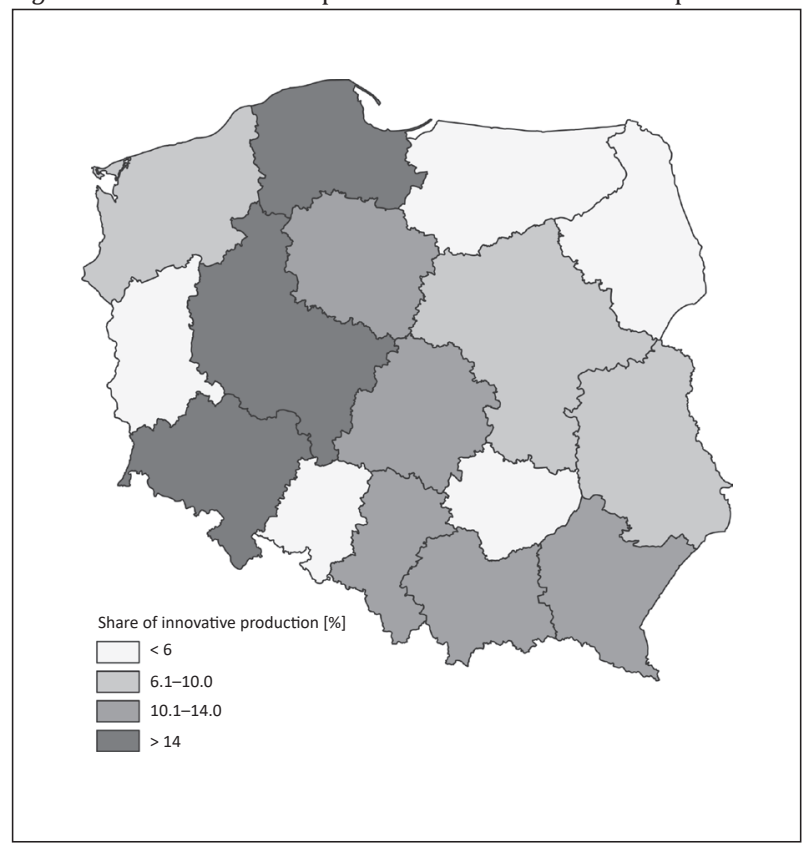

Source: own work based on Bank Danych Lokalnych (2017) and Działalność innowacyjna... (2016) 
Fig. 8. Change in the share of innovative products in industrial enterprises in the total value of sales in 2005-2015

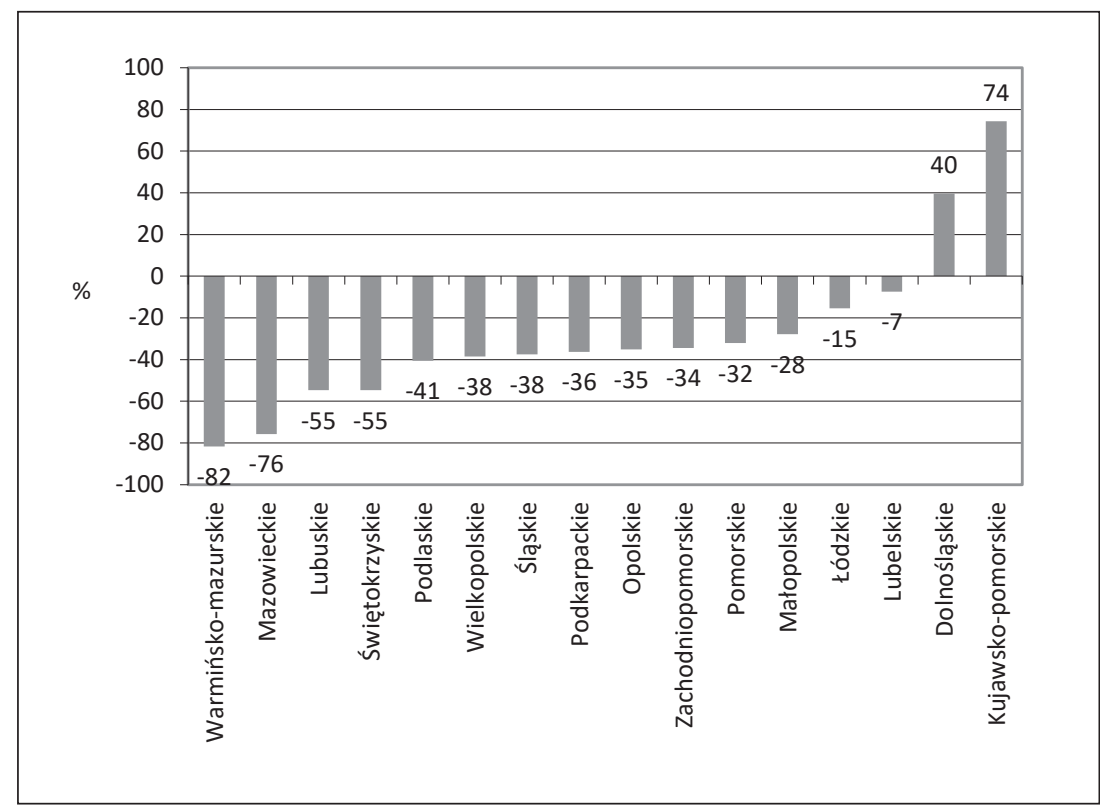

Source: own work based on Bank Danych Lokalnych (2017) and Działalność innowacyjna... $(2013,2016)$

Fig. 9. Change in the share of net revenues from sales of innovative products in total revenues in 2005-2015

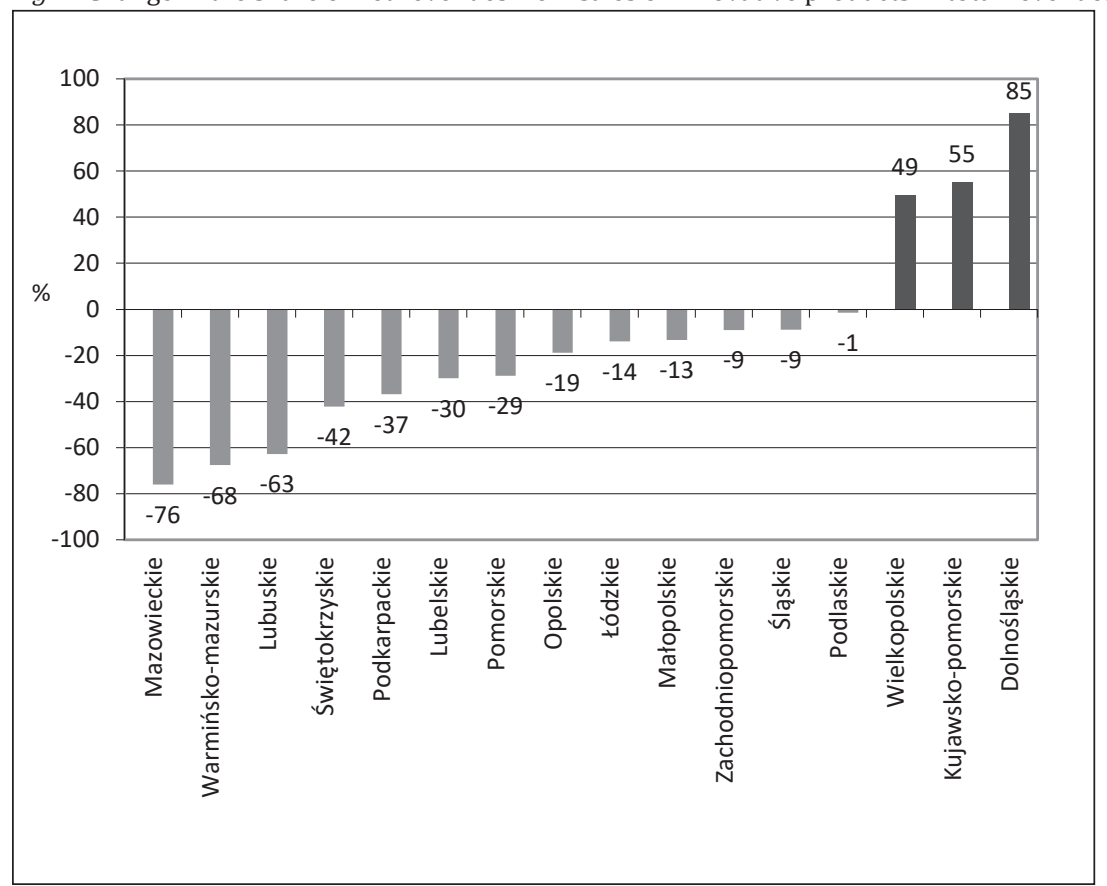

Source: own work based on Bank Danych Lokalnych (2017) and Działalność innowacyjna... (2016) 
were also contributed by the decline in the share of innovative industrial enterprises in Poland in total enterprises mentioned in this article. The above-described processes influenced, among others, the significant drop in innovative production sold in the value of total sold production in 2015 to 2005 . This share in the country scale decreased by nearly $45 \%$. Thus, the above regularity occurred in the majority of the voivodeships of the country in the analysed period (Fig. 8).

The most considerable reduction in the share of the value of innovative production occurred mainly in economically weak voivodeships (Warmińsko-Mazurskie, Lubelskie, Świętokrzyskie) but also in Mazowieckie Voivodeship. On the other hand, increases occurred in two voivodeships: Dolnośląskie - by $40 \%$ and the largest in Kujawsko-Pomorskie - by $74 \%$.

The spatial distribution of the share of innovative products sold in the value of sold product in total in 2015 corresponded to the spatial diversity of the share of net revenues from the sale of innovative products in total revenues. It is another parameter showing the effectiveness of innovative expenditure in industrial enterprises. In this case, in the studied period, the change in the share of revenues from innovative products showed high similarity with the change in the share of innovative products sold in individual voivodeships. The most significant decrease in the share was characteristic of Mazowieckie Voivodeship, followed by Warmińsko-Mazurskie and Lubuskie Voivodeships. The region of voivodeships with the increase in the share of revenues from the sale of innovative products, Dolnośląskie and Kujawsko-Pomorskie Voivodeships was joined by Wielkopolskie Voivodeship (Fig. 9).

\section{CHANGES IN THE SPATIAL STRUCTURE OF INNOVATION IN THE POLISH INDUSTRY IN SYNTHETIC TERMS}

In the economical-geographical studies of the structure of spatial systems, the analytical side of the issue dominates, as evidenced by the first part of the present article. It was devoted to selected issues of innovativeness of the spatial structure of the Polish industry by voivodeship. Attention was drawn to the analysis of elements of industry innovation creating specific spatial structures and changes in them in 2005-2015. However, they did not allow to determine the overall change of the studied phenomenon in a given period. Therefore, in the following part, an attempt was made to synthetically characterise the changes in the spatial system of industry innovation in the mentioned years. Conducting synthetic research results from the conviction that other types of changes characterise the system as a whole, than those that particular concern elements of the spatial layout.

The spatial structure of innovation of Polish industry in the analysed period was determined by the share of particular voivodeships in the total size of meta-features in quasi one-feature research and the volume of expenditures borne by industrial enterprises for innovative activities in one-feature research.

In 2005-2015, the spatial structure of industry innovation in Poland showed very high stability. Changes in the spatial structure on the basis of meta-features accepted for the research were insignificant, which is indicated by $\cos _{2005,2015}$ amounting to 0.993306 . The calculated arc cosine function gives an angle of $6^{\circ} 63^{\prime}$. This means that the spatial structure of innovativeness of Polish industry in 2015 had changed only slightly, i.e. in less than $4 \%$ as compared to 2005 . To determine only the size of the 
Fig. 10. Changes in the spatial structure of innovativeness of Polish industry in the years 2005-2015

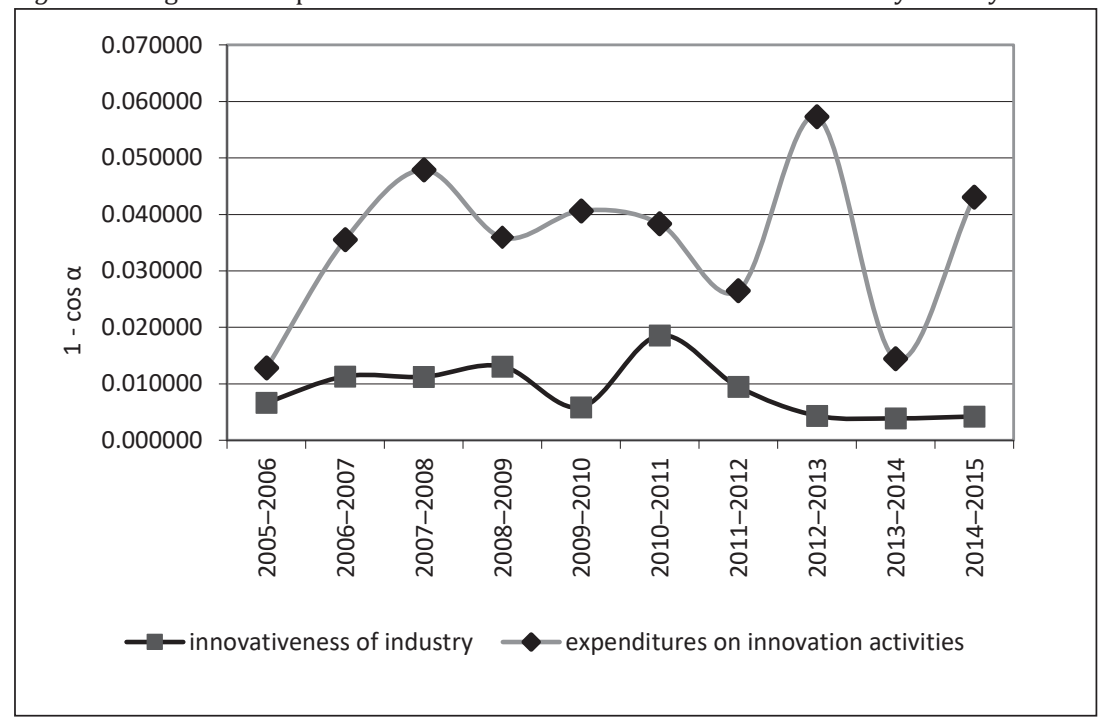

Source: own work based on Bank Danych Lokalnych (2017) and Działalność innowacyjna... (2013, 2016)

changes in the spatial structure of industry innovation in individual years of the period 2005-2015, a slightly different interpretation had to be given to the calculated function $\cos \mathrm{K}_{\mathrm{j}}^{\prime} \mathrm{K}_{\mathrm{k}^{*}}^{\prime}$ The measure of changes in the structure is expressed by $\left(1-\cos \mathrm{K}_{\mathrm{j}}^{\prime} \mathrm{K}_{\mathrm{k}}^{\prime}\right)$. The analysis of the results shows that slightly larger structural fluctuations (in the case of small ones in the entire period) took place in 2010-2011 and 2008-2009. In terms of the period 2012-2013, changes in the spatial structure took on the character of small, fixed-size changes (Fig. 10).

In the analysed period, much more significant changes in the spatial structure took place in the case of expenditure on innovative activity in industrial enterprises by voivodeship. The analysis of the size of changes in the structure of inputs indicates that more considerable structural fluctuations took place in 2012-2013, 2007-2008 and 2014-2015. However, the minimum structural changes concerned the years 20052006 and 2013-2014 (Fig. 10). The mentioned structural changes had an abrupt and irregular character, which may confirm the ad hoc and non-systemic nature of innovative activity in the analysed period. In the case of expenditure on innovative activity in industrial enterprises in the years 2005-2015, the spatial structure was less stable than in the case of the whole set of innovation characteristics, as evidenced by $\cos _{2005,2015}$, which amounted to 0.956757 . The calculated arc cosine gives an angle of $16^{\circ} 91^{\prime}$. It means that the spatial structure of expenditures on innovative activity in Polish industry in 2015 changed in less than 10\% in relation to 2005. However, greater stability of spatial distribution of other features reduced the impact of changes in innovative expenditure in enterprises on changes in the entire industry innovation structure.

An expression of the substantial stability of the spatial structure of the innovativeness of Polish industry in the analysed period is also small changes in the classification of voivodeships from the point of view of their participation in the national structure of the studied phenomenon. In 2015, only Lubelskie Voivodeship shifted from the average share class in 2005 to the small share class (Tab. 1). 
Tab. 1. Classification of voivodeships from the point of view of participation in industry innovation

\begin{tabular}{|l|l|l|}
\hline \multicolumn{1}{|c|}{ Share } & \multicolumn{2}{c|}{ Voivodeship 2015 } \\
\hline \multirow{5}{*}{ low } & Lubuskie & Lubuskie \\
\cline { 2 - 3 } & Opolskie & Lubelskie \\
\cline { 2 - 3 } & Podlaskie & Opolskie \\
\cline { 2 - 3 } & Świętokrzyskie & Podlaskie \\
\cline { 2 - 3 } & Warmińsko-mazurskie & Warmińsko-mazurskie \\
\cline { 2 - 3 } & Zachodniopomorskie & Świętokrzyskie \\
\cline { 2 - 3 } & & Zachodniopomorskie \\
\hline \multirow{5}{*}{ medium } & Łódzkie & Łódzkie \\
\cline { 2 - 3 } & Kujawsko-pomorskie & Kujawsko-pomorskie \\
\cline { 2 - 3 } & Lubelskie & Pomorskie \\
\cline { 2 - 3 } & Pomorskie & Podkarpackie \\
\cline { 2 - 3 } & Podkarpackie & \\
\hline \multirow{5}{*}{ high } & Wielkopolskie & Wielkopolskie \\
\cline { 2 - 3 } & Śląskie & Śląskie \\
\cline { 2 - 3 } & Mazowieckie & Mazowieckie \\
\cline { 2 - 3 } & Dolnośląskie & Dolnośląskie \\
\cline { 2 - 3 } & Małopolskie & Małopolskie \\
\hline
\end{tabular}

Source: own work based on Bank Danych Lokalnych (2017) and Działalność innowacyjna... (2016)

However, more substantial shifts were observed in the classification of spatial units from the point of view of their share in innovative expenditure in industrial enterprises (Tab. 2).

Tab. 2. Classification of voivodeships from the point of view of the share in expenditure on innovative activity in industrial enterprises

\begin{tabular}{|l|l|l|}
\hline \multicolumn{1}{|c|}{ Share } & \multicolumn{1}{|c|}{ Voivodeship 2005 } & \multicolumn{1}{c|}{ Voivodeship 2015 } \\
\hline low & Lubuskie & Lubelskie \\
\hline & Opolskie & Opolskie \\
\hline & Podlaskie & Podlaskie \\
\hline & Świętokrzyskie & Warmińsko-mazurskie \\
\hline & Warmińsko-mazurskie & Kujawsko-pomorskie \\
\hline & Zachodniopomorskie & Świętokrzyskie \\
\hline medium & Łódzkie & Zachodniopomorskie \\
\hline & Kujawsko-pomorskie & Łódzkie \\
\hline & Lubelskie & Pomorskie \\
\hline & Dolnośląskie & Podkarpackie \\
\hline & Pomorskie & Małopolskie \\
\hline & Małopolskie & \\
\hline high & Podkarpackie & Wielkopolskie \\
\hline & Wielkopolskie & Dolnośląskie \\
\hline & Śląskie & Mazowieckie \\
\hline & Mazowieckie & Śląskie \\
\hline
\end{tabular}

Source: own work based on Bank Danych Lokalnych (2017) and Działalność innowacyjna... (2016) 
In this case, transfers to other share classes concerned a more significant number of spatial units. The voivodeships that shifted from the average share class in 2005 to the low share class in 2015 included not only Lubelskie Voivodeship but also Kujawsko-Pomorskie Voivodeship. Besides, Zachodniopomorskie and Łódzkie Voivodeships were upgraded in 2015 from the low share class to the medium share class, while Dolnośląskie Voivodeship joined the group of leaders with Wielkopolskie, Śląskie and Mazowieckie Voivodeships.

The research conducted indicates high stability of the spatial structure of the innovativeness of Polish industry with the dominance of voivodeships with large urban agglomerations and a developed industrial function having a significant impact on the innovative activity of enterprises located in their area (see Śleszyński, 2009). These regions often form a diversified research-scientific and economic environment and thus can foster innovative activities for industry. It should be emphasised that there is also no significant reduction in the disproportions in industry innovation or the distribution of expenditure on innovative activity for individual spatial units, as evidenced by the estimated volatility co-efficients for innovation in the industry in $2005-78.2 \%$, and in $2015-77.8 \%$. The same is true for innovative investments in industrial enterprises where volatility co-efficients were higher and amounted to $99.4 \%$ and $96.9 \%$, respectively.

Also worth emphasising is the emergence of new spatial units that may soon join the leaders of innovative industry, such as Podkarpackie Voivodeship. The diverse type structure of business entities in its area with a significant representation of the production of communication equipment and chemical products, as well as the accompanying large BERD expenditures in relation to other voivodeships in the country can be the basis. The more so because the effects of outlays on R\&D or innovative activity in industrial enterprises lag behind the period of their incurring.

\section{SUMMARY}

In the years 2005-2015 there was an increase in expenditures on R\&D and innovative activity in Poland. However, the obtained values are highly unsatisfactory. The spatial structure of innovation of the Polish industry shows considerable spatial diversification by voivodeship. Despite a significant decrease in the share of innovative enterprises in total enterprises, in the majority of voivodeships there was an increase in expenditures on innovative activities. In most of the voivodeships, the decline in the share of innovative products in the total value of sales (with the exception of Dolnośląskie and Kujawsko-Pomorskie Voivodeships) was a disadvantageous phenomenon in the analysed period, and the share of net revenues from sales of innovative products in total revenues decreased (with the exception of Dolnośląskie, Kujawsko-Pomorskie and Wielkopolskie). It is worth noting the low effectiveness of innovative expenditure in the face of a progressive decline in the share of the value of manufacturing innovative products and a decrease in the share of revenues from their sale.

In the years 2005-2015, the spatial structure of industry innovation in Poland showed high stability. Changes in the spatial structure were insignificant. In the synthetic approach, the spatial structure of innovation in Polish industry changed only in $4 \%$. An expression of the stability of the spatial structure in the analysed period are also small changes in the classification of voivodeships from the point of view of their share 
in the national structure of the studied phenomenon. More substantial transformations of the industry's innovation structure (often of an abrupt and irregular nature) take place in the arrangements related to its specific characteristics, in particular outlays for innovative activity in industrial enterprises and between subsequent years of the 2005-2015 period.

The conducted research indicates the need to increase expenditures on research and development activities in Polish voivodeships, especially those carried out in industrial enterprises, increasing the efficiency of current expenditures on innovative activities in industry, as well as increasing investment attractiveness of weaker voivodeships (especially eastern and north-eastern Poland) to reduce disproportion of regional innovation in Polish industry.

The issue of the change in the spatial structure of industry innovation discussed in the study indicates the need to research regional approaches. The regularities identified as a result of such research provide the basis for more efficient management of the economy and enable undertaking actions aimed at the desired transformations of the spatial structures under examination.

\section{References}

Aydalot, Ph. (1986). Milieux innovateuras en Europe [Innovative environments in Europe]. Paris: GREMI.

Bank Danych Lokalnych Głównego Urzędu Statystycznego [Local Data Bank of the Central Statistical Office] (2017, 12 października). Pozyskano z: http://www.stat.gov.pl/bdl/app/ strona.html?p_name=indeks

Brezdeń, P. (2015). Wybrane aspekty przemian strukturalnych i innowacyjności przemysłu Śląska - ujęcie przestrzenne [Selected Aspects of the Structural Changes and the Innovativeness of Silesian Industry - a Spatial Perspective]. Prace Komisji Geografii Przemysłu Polskiego Towarzystwa Geograficznego [Studies of the Industrial Geography Commission of the Polish Geographical Society], 29(2), 123-146.

Brezdeń, P. (2016). Wybrane aspekty wpływu kapitału zagranicznego na gospodarkę Dolnego Śląska - ujęcie przestrzenne [Selected Aspects of the Influence of Foreign Capital on the Lower Silesia Economy - a Spatial Perspective]. Prace Komisji Geografii Przemysłu Polskiego Towarzystwa Geograficznego [Studies of the Industrial Geography Commission of the Polish Geographical Society], 30(2), 72-94.

Brezdeń, P., Spallek, W. (2013). Przestrzenne zróżnicowanie poziomu innowacyjności regionalnej gospodarki województwa dolnośląskiego [Spatial Differentiation of the Level of Innovation of Regional Economy of Lower Silesian Voivodeship]. Prace Komisji Geografii Przemysłu Polskiego Towarzystwa Geograficznego [Studies of the Industrial Geography Commission of the Polish Geographical Society], 23, 9-25.

Carnicky, S., Krupa, K., Skotny, P. (2011). Business Intelligence. Theory and Practice. RzeszówKoszyce.

Diagnoza pogłębiona innowacyjności gospodarki Małopolski. Opracowanie przygotowane na potrzeby prac nad Regionalna Strategia Innowacji Województwa Małopolskiego na lata 20132020 [Diagnosis deepened by the innovativeness of the Małopolska economy. Prepared for the needs of work on the Regional Innovation Strategy of the Małopolska Region for the years 2013-2020] (2012). Kraków: Urząd Marszałkowski Województwa Małopolskiego.

Działalność innowacyjna przedsiębiorstw w latach 2010-2012 [Innovative activity of enterprises in 2010-2012] (2013). Informacje i opracowania statystyczne. Szczecin: Urząd Statystyczny w Szczecinie.

Działalność innowacyjna przedsiębiorstw w latach 2013-2015 [Innovation activity of enterprises in 2013-2015] (2016). Informacje i opracowania statystyczne. Szczecin: Urząd Statystyczny w Szczecinie. 
Dzikowski, P. (2017). Wpływ odległości od konkurenta, dostawcy i odbiorcy na aktywność innowacyjną przedsiębiorstw przemysłu średnio niskiej techniki w Polsce [The Impact of Spatial Proximity to Competitor, Supplier and Customer on Innovation Activity in Medium-Low Industry in Poland]. Prace Komisji Geografii Przemysłu Polskiego Towarzystwa Geograficznego [Studies of the Industrial Geography Commission of the Polish Geographical Society], 31(1), 24-37.

Etzkowitz, H., Leydesdorff, L. (2000). The Dynamics of Innovation, From National System and "Mode 2", to a Triple Helix of University-Industry-Government Relations. Research Policy, $29,109-123$.

Gajda, W. (2015). Innowacyjność polskiego przemysłu na tle przemysłu światowego [Innovativeness of Polish industry against the global industry]. Prace Komisji Geografii Przemystu Polskiego Towarzystwa Geograficznego [Studies of the Industrial Geography Commission of the Polish Geographical Society], 29(1), 42-55.

Golejowska, A. (2012). Innowacyjność a konkurencyjność regionalna krajów Grupy Wyszehradzkiej w latach 1999-2008 [Innovation and regional competitiveness in the Visegrad Group, 1999-2008]. Prace Komisji Geografii Przemysłu Polskiego Towarzystwa Geograficznego [Studies of the Industrial Geography Commission of the Polish Geographical Society], 19, 93-115.

Klamut, M. (1996). Ewolucja struktury gospodarczej w krajach wysoko rozwiniętych [The evolution of the economic structure in highly developed countries]. Wrocław: Uniwersytet Ekonomiczny we Wrocławiu.

Kukliński, A. (1997). Regionalne systemy innowacji (RSI) w Polsce. Doświadczenia i perspektywy [Regional innovation systems (RIS) in Poland. Experience and perspectives]. In: A. Kukliński (ed.). Problematyka przestrzeni europejskiej [The problems of European space]. Warszawa: EUROREG.

Langendijk, A. (2001). Regional learning between variation and convergence: The concept of 'mixed-land-use' in regional spatial planning in the Netherlands. Canadian Journal of Regional Science, 24(1), 136-155.

Maillat, D. (2002). Globalizacja, terytorialne systemy produkcyjne $i$ środowiska innowacyjne [Globalisation, territorial production systems and innovative environments]. Kraków: Wydawnictwo Akademii Ekonomicznej.

Marinowa, D., Philimore, J. (2003). Model of innovation. In: L.V. Shavinina (ed.). The International Handbook on Innovation. Oxford, Elsvier, 44-53.

Markowski, T. (2005). Współczesne uwarunkowania polityki innowacyjnej w regionach [Contemporary determinants of innovation policy in regions]. In: F. Kuźnik (ed.). Studia regionalne w Polsce [Regional studies in Poland]. Katowice: Wyższa Akademia Ekonomiczna.

Meyer-Krahmer, F., Gundrum, U. (1995). Innovationsförderung inm ländlichen Raum [Promotion of innovation in rural areas]. Raumforschung und Raumordnung [Space research and spatial planning], 53(3), 177-185.

Murzyn, D. (2013). Wpływ wykorzystania funduszy strukturalnych w Małopolsce na rozwój sieci współpracy i innowacyjności regionu [The Impact of Structural Funds in Małopolska for the Development of Networks and Regional Innovation]. Prace Komisji Geografii Przemysłu Polskiego Towarzystwa Geograficznego [Studies of the Industrial Geography Commission of the Polish Geographical Society], 23, 104-117.

Nauka i technika w 2012 r. Science and technology in Poland in 2012 (2013). Informacje i opracowania statystyczne. Szczecin: Urząd Statystyczny w Szczecinie.

Nauka i technika w 2015 r. Science and technology in Poland in 2015 (2016). Informacje i opracowania statystyczne. Warszawa: Urząd Statystyczny w Szczecinie.

Nowak, P. (2012). Poziom innowacyjności polskiej gospodarki na tle krajów UE [Poland's innovative position against the background of other EU countries]. Prace Komisji Geografii Przemysłu Polskiego Towarzystwa Geograficznego [Studies of the Industrial Geography Commission of the Polish Geographical Society], 19, 153-168.

Olechnicka, A., Smętkowski, M. (2007). Wpływ technologii teleinformacyjnych na rozwój regionu peryferyjnego na przykładzie województwa podlaskiego [Influence of teleinformation technologies on the development of the peripheral region on the example of the Podlasie Voivodeship]. Studia Regionalne i Lokalne, 4(30), 48-65. 
Oughton, Ch., Landabaso, M., Morgan, K. (2002). The regional innovation paradox: Innovation policy and industrial policy. Journal of Technology Transfer, 27(1), 97-110.

Parysek, J. (1976). Zmiany struktury przestrzennej przemysłu Polski w latach 1960-1973. Próba miernika syntetycznego [Changes in the spatial structure of Polish industry in the years 1960-1973. Trial of a synthetic meter]. Przegląd Geograficzny, 48(2), 253-268.

Pfirrmann, 0. (1994). The geography of innovation in small and medium-sized firms in West Germany. Small Business Economics, 6(1), 27-41.

Podręcznik Oslo. Zasady gromadzenia i interpretacji danych dotyczacych innowacji [Rules for collecting and interpreting data on innovation] (2008). Warszawa: OECD, Eurostat, Ministerstwo Nauki i Szkolnictwa Wyższego.

Rachwał, T. (2008). Problematyka badawcza funkcjonowania przedsiębiorstw przemysłowych [Research problems concerning the functioning of industrial enterprises]. Prace Komisji Geografii i Przemysłu Polskiego Towarzystwa Geograficznego [Studies of the Industrial Geography Commission of the Polish Geographical Society], 11, 53-85.

Rachwał, T. (2009). Problematyka badawcza zmian powiązań przestrzennych przedsiębiorstw przemysłowych [Research issues of changes in spatial relations of industrial enterprises]. Studia i Prace Uniwersytetu Ekonomicznego w Krakowie, 8, 157-176.

Rachwał, T. (2012). Innowacyjność przedsiębiorstw przemysłowych jako czynnik rozwoju miast [Innovation of industrial enterprises as a factor of urban development]. In: Z. Makieła, A. Szromnik (eds.). Miasto innowacyjne - wiedza - przedsiębiorczość - marketing [Innovative city - knowledge - entrepreneurship - marketing]. Warszawa: Komitet Przestrzennego Zagospodarowania Kraju, 135-151.

Rachwał, T., Wiedermann, K., Kilar, W. (2009). Rola przemysłu w gospodarce układów regionalnych Unii Europejskiej [The role of industry in economy of European Union regional systems]. Prace Komisji Geografii Przemysłu Polskiego Towarzystwa Geograficznego [Studies of the Industrial Geography Commission of the Polish Geographical Society], 14, 31-42.

Runge, J. (2006). Metody badań w geografii społeczno-ekonomicznej - elementy metodologii, wybrane narzędzia badawcze [Research methods in socio-economic geography - elements of methodology, selected research tools]. Katowice: Wydawnictwo Uniwersytetu Śląskiego.

Schmookler, J. (1972). Patents, Invention and Economic Change: Data and Selected Essays. Cambridge.

Schumpeter, J.A. (1995). Kapitalizm, socjalizm, demokracja [Capitalism, socialism, democracy]. Warszawa: Wydawnictwo Naukowe PWN.

Siłka, P. (2012). Typologia miast ze względu na potencjał innowacyjny [Typology of cities based on innovation potential]. Prace Komisji Geografii Przemysłu Polskiego Towarzystwa Geograficznego [Studies of the Industrial Geography Commission of the Polish Geographical Society], 19, 61-73.

Sternberg, R., Arndt, O. (2000). The firm or the region - what determines European firms' innovation behavior? Working Paper. University of Cologne, Department of Economic and Social Geography, 2, 3-7.

Stryjakiewicz, T., Męczyński, M. (2010). Atrakcyjność poznańskiego obszaru metropolitalnego dla pracujacych w sektorze kreatywnym [Attractiveness of the Poznań metropolitan area for those working in the creative sector]. Poznań: Bogucki wydawnictwo Naukowe.

Stryjakiewicz, T., Stachowiak, K. (2010). Uwarunkowania, poziom i dynamika rozwoju sektora kreatywnego $w$ poznańskim obszarze metropolitalnym [The conditions, level and dynamics of the creative sector development in the Poznań metropolitan area]. Poznań: Bogucki Wydawnictwo Naukowe.

Śleszyński, P. (2009). Zmiany strukturalne i przestrzenno-funkcjonalne w rozwoju przedsiębiorczości po przystąpieniu Polski do Unii Europejskiej [Structural and spatial-functional changes in the development of entrepreneurship after Poland's accession to the European Union]. Studia Regionalne i Lokalne, 3(37), 5-26.

Wach, K. (2007). Wpływ potencjału innowacyjnego Małopolski i Śląska na rozwój małych i średnich przedsiębiorstw w świetle badań empirycznych. Wiedza i innowacje rozwoju polskich regionów: siły i motoryczne i bariery [Influence of the innovative potential of Małopolska and Silesia on the development of small and medium enterprises in the light of empirical 
research. Knowledge and innovations in the development of Polish regions: motor forces and barriers]. Gdańsk: Fundacja Rozwoju Uniwersytetu Gdańskiego.

Winiarski, B. (2002). Polityka gospodarcza [Economic policy]. Warszawa: Wydawnictwo Naukowe PWN.

Zioło, Z. (1985). Zastosowanie miernika syntetycznego w badaniach układów przestrzennych geografii przemysłu [The use of a synthetic meter in the study of spatial layouts of industrial geography]. Seminarium Komisji Geografii Przemysłu Polskiego Towarzystwa Geograficznego. Kraków: Wyższa Szkoła Pedagogiczna im. KEN, 1-11.

Zioło, Z. (2010). Uwarunkowania kształtowania się procesów transformacji przemysłu i usług [Conditions shaping transformational processes in industry and services]. Prace Komisji Geografii Przemysłu Polskiego Towarzystwa Geograficznego [Studies of the Industrial Geography Commission of the Polish Geographical Society], 15, 45-60.

Zioło, Z. (2012). Miejsce innowacyjności w kształtowaniu procesów rozwoju gospodarczego układów przestrzennych [Position of innovativeness in the processes of economic development of spatial structures]. Prace Komisji Geografii Przemysłu Polskiego Towarzystwa Geograficznego [Studies of the Industrial Geography Commission of the Polish Geographical Society], 20, 9-32.

Paweł Brezdeń, Ph.D., an assistant professor in the Department of Socio-Economic Geography at the University of Wroclaw. His research interests focus on investment processes, banking industry, entrepreneurship and economic revival, the networked economy, structure of industry and innovativeness. Also, he is researching the field of demography and population, management and marketing. He is a co-author of three popular atlases and socio-economic monographs.

\title{
Address:
}

\author{
University of Wroclaw \\ Institute of Geography and Regional Development \\ Department of Socio-Economic Geography \\ pl. Uniwersytecki 1, 50-137 Wrocław, Poland \\ e-mail: pawel.brezden@uwr.edu.pl
}

